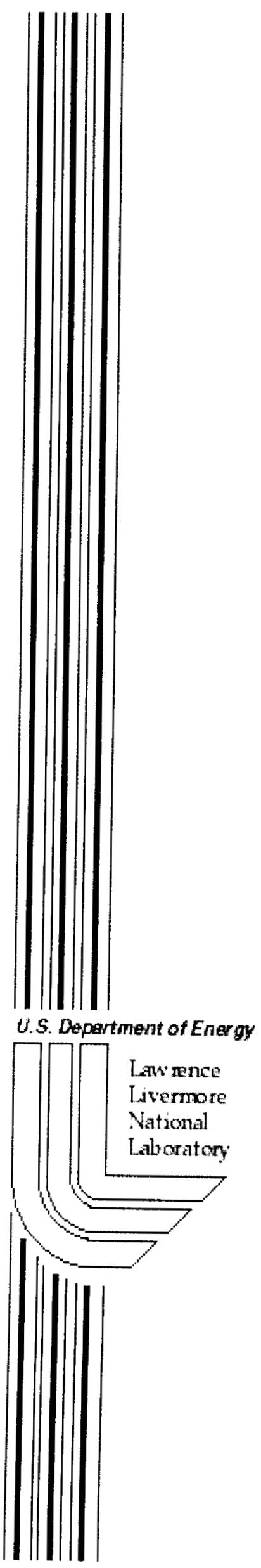

UCRL-ID-151954

\title{
Radiological Conditions on Rongelap Atoll: Diving and Fishing on and Around Rongelap Atoll
}

\author{
T.F. Hamilton
}

February 20, 2003 


\section{DISCLAIMER}

This document was prepared as an account of work sponsored by an agency of the United States Government. Neither the United States Government nor the University of California nor any of their employees, makes any warranty, express or implied, or assumes any legal liability or responsibility for the accuracy, completeness, or usefulness of any information, apparatus, product, or process disclosed, or represents that its use would not infringe privately owned rights. Reference herein to any specific commercial product, process, or service by trade name, trademark, manufacturer, or otherwise, does not necessarily constitute or imply its endorsement, recommendation, or favoring by the United States Government or the University of California. The views and opinions of authors expressed herein do not necessarily state or reflect those of the United States Government or the University of California, and shall not be used for advertising or product endorsement purposes.

This work was performed under the auspices of the U. S. Department of Energy by the University of California, Lawrence Livermore National Laboratory under Contract No. W-7405-Eng-48.

This report has been reproduced directly from the best available copy.

Available to DOE and DOE contractors from the Office of Scientific and Technical Information

P.O. Box 62, Oak Ridge, TN 37831

Prices available from (423) 576-8401

http://apollo.osti.gov/bridge/

Available to the public from the National Technical Information Service

U.S. Department of Commerce 5285 Port Royal Rd., Springfield, VA 22161 http://www.ntis.gov/

OR

Lawrence Livermore National Laboratory Technical Information Department's Digital Library http://www.llnl.gov/tid/Library.html 


\section{Radiological Conditions on Rongelap Atoll}

\section{Diving and fishing on and around Rongelap Atoll}

Rongelap Atoll experienced close-in "local fallout" from nuclear weapons tests conducted by the United States (1946-58) in the northern Marshall Islands. Most of the radiation dose delivered to Rongelap Island residents during the 1950 s was from radioactive elements that quickly decayed into non-radioactive elements. Since 1985, the Lawrence Livermore National Laboratory (LLNL) has continued to provide monitoring of radioactive elements from bomb testing in the terrestrial and marine environment of Rongelap Atoll. The only remaining radioactive elements of environmental importance at the atoll are radioactive cesium (cesium-137), radioactive strontium (strontium-90), different types (isotopes) of plutonium, and americium (americium-241). Cesium-137 and strontium-90 dissolve in seawater and are continually flushed out of the lagoon into the open ocean. The small amount of residual radioactivity from nuclear weapons tests remaining in the lagoon does not concentrate through the marine food chain.

Elevated levels of cesium-137 and strontium-90 are still present in island soils and pose a potential health risk if certain types of local plants and coconut crabs are eaten in large quantities. Cesium-137 is taken up from the soil into plants and edible food products, and may end up in the body of people living on the islands and consuming local food. The presence of cesium-137 in the human body can be detected using a device called a whole body counter. A person relaxes in a chair for a few minutes while counts or measurements are taken using a detector a few inches away from the body. The whole body counting program on Rongelap Island was established in 1999 under a cooperative agreement between the Rongelap Atoll Local Government (RALG), the Republic of the Marshall Islands and the U.S. Department of Energy (DOE). Local technicians from Rongelap continue to operate the facility under supervision of scientists from LLNL. The facility permits resettlement workers living on Rongelap Island to check the amount of cesium-137 in their bodies. ${ }^{1}$ The amount of cesium-137 detected in resettlement workers living on Rongelap Island over the past three years is well below the level of radiation exposure considered safe by the Nuclear Claims Tribunal. Returning residents and visitors to Rongelap will also be able to receive a whole body count free of charge to check the level of cesium in their bodies. There is also a very low health risk from exposure to external sources of radiation from visiting or walking around any of the islands on the atoll.

The residual levels of plutonium and americium-241 in Rongelap lagoon are elevated over what might be expected from global dispersion of radioactive debris from worldwide

\footnotetext{
${ }^{1}$ Resettlement workers presently living on Rongelap Island receive an average internal dose from cesium-137 of less than 1 mrem $(0.01 \mathrm{mSv})$ per year. V. E. Noshkin and others in: The Science of the Total Environment 1994, 155:87-104, report that a person eating fish as part of a typical local diet in the Marshall Islands receives a dose of about $100 \mathrm{mrem}(1 \mathrm{mSv})$ per year from the radioactivity in fish that is natural and not related to bomb testing. According to the United Nations Scientific Committee on the Effects of Atomic Radiation, in Sources and effects of ionizing radiation, 2000 Report to the General Assembly, the worldwide average natural background dose is 240 mrem $(2.4 \mathrm{mSv})$ per year.
} 
atmospheric nuclear weapons testing. ${ }^{2}$ Most of the plutonium remains fixed in bottom sediments while only a small amount is dissolved in the surrounding seawater. As plutonium and americium-241 decay they emit alpha particles. Alpha particles can only travel a few micrometers in water. ${ }^{3}$ Consequently, plutonium is not an underwater external exposure hazard because the alpha particles are absorbed either by the water or in divers' wetsuits or outside layer of skin. The primary route of exposure to these alpha-emitting elements is from inhalation and ingestion. There is little chance for inhalation exposure to these radionuclides while diving or swimming in the lagoon and it is also highly unlikely that a diver would ingest significant quantities of sediment. Moreover, plutonium is not readily transferred from soils to plants nor is there significant adsorption of plutonium through the gut of marine organisms or animals (including man). The main concern for inhalation exposure of plutonium is via the dust in air that people breath while residing on the islands. Scientists from LLNL measure plutonium exposure in resettlement workers and continue to provide monitoring of plutonium concentrations in air. These data show that worker exposures to plutonium are less than $0.02 \mathrm{mrem}(0.0002 \mathrm{mSv})$ per year. At this annual dose a population the size of the Marshall Islands, over many generations, would not be expected to experience additional cancer deaths above the number expected in a similar sized population that was not exposed. Under the guidelines adopted by the Republic of the Marshall Islands Nuclear Claims Tribunal diving, fishing and visiting any island of Rongelap Atoll are deemed safe activities for limited periods. Eating local fish and other marine life such as clams would also be considered safe.

Dr. Terry Hamilton

Lawrence Livermore National Laboratory

\footnotetext{
${ }^{2}$ Based on research by Dr. Terry Hamilton, Lawrence Livermore National Laboratory.

${ }^{3} 1$ micrometer $=0.000001$ meter or 0.00004 inch
} 